\title{
Morphometric abnormalities in spleen and kidney of the progeny of mice fed American cranberry extract (Vaccinium macrocarpon) during pregnancy and lactation
}

\author{
B.J. Bałan ${ }^{1}$, S. Lewicki ${ }^{2}$, A.K. Siwicki ${ }^{3}$, M. Stelmasiak ${ }^{1}$, P. Skopiński ${ }^{4}$, \\ E. Skopińska-Różewska ${ }^{5}$, A. Wasiutyński ${ }^{6}$, R. Zdanowski ${ }^{2}$
}

\author{
${ }^{1}$ Department of Immunology, Biochemistry and Nutrition, \\ Warsaw Medical University, Oczki 3, 02-007, Warsaw, Poland \\ ${ }^{2}$ Department of Regenerative Medicine and Cell Biology, Military Institute of Hygiene and Epidemiology, \\ Kozielska 4, 01-163, Warsaw, Poland \\ ${ }^{3}$ Department of Microbiology and Clinical Immunology, \\ University of Warmia and Mazury, Oczapowskiego 13, 10-957 Olsztyn, Poland \\ ${ }^{4}$ Department of Histology and Embryology \\ ${ }^{5}$ Pathomorphology Department, Center for Biostructure Research, \\ Warsaw Medical University, Chałubińskiego 5, 02-004, Warsaw, Poland \\ ${ }^{6}$ Pathomorphology Department, National Institute of Geriatrics, \\ Rheumatology and Rehabilitation, Spartańska 1, 02-637 Warsaw, Poland
}

\begin{abstract}
Cranberries and cranberry-derived diet supplements are often recommended for the treatment of urinary tract infections, also during pregnancy. These products contain strongly anti-angiogenic chemical compounds which could not be indifferent to the developing fetus. In the present work we evaluated the effect of feeding pregnant and lactating mice American cranberry extract (daily dose $0.88 \mathrm{mg}$ ) on the morphology and some parameters of spleen and kidney function of their adult progeny. Six weeks after delivery the morphometry of spleen and kidney, cytometric analysis of spleen lymphocytes, evaluation of humoral response to SRBC (Sheep Red Blood Cells), and examination of serum creatinine/urea concentration, were performed in the offspring. Spleens of progeny from experimental (E) group differed from the spleens of progeny of control mice in the lower number of lymphatic nodules and their larger diameter. Cytometry of spleen cells from progeny of $\mathrm{E}$ mothers revealed more $\mathrm{CD} 19^{+}$and $\mathrm{CD} 8^{+}$lymphocytes than in the control group. No difference was seen in the response to immunization by red blood cells of sheep (SRBC) between control and $\mathrm{E}$ offspring. An increase in the diameter of glomeruli was observed in the kidneys of the experimental group in comparison with the control group. No abnormalities in creatinine and urea serum level were observed. A higher concentration of VEGF and bFGF in E offspring sera in comparison to the controls was seen. Conclusion: Although the observed differences between the control and experimental group were not large, caution is recommended in using cranberries and their extracts during pregnancy until more research will be done on this topic.
\end{abstract}

Key words: mice, cranberry, pregnancy, offspring, morphometry, kidney, spleen, CD8 and CD19 lymphocytes 


\section{Introduction}

Treatment of infections during pregnancy is problematic. Many antibiotics have a number of side effects and may adversely affect the developing fetus. The FDA (Food and Drug Administration) has divided commonly used antibiotics into five categories, which determine the risk of their use: A (no risk in controlled human studies), B (no risk in animal reproduction studies), C (risk not ruled out), D (positive evidence of risk), $\mathrm{X}$ (contraindicated in pregnancy), where only group A is generally considered as safe for use during pregnancy (Hecht 1979).

Previous research conducted on the pregnant mouse model confirmed the validity of this division. Animals born to mothers fed during pregnancy with antibiotics, which belong to the penicillins and cephalosporins group (classified as B group), exhibited an altered reactivity of the immune system expressed by decreased intensity of cellular, and increased intensity of humoral, immunity (Skopińska-Różewska et al. 1985, Włodarska et al. 1987). It is not surprising that attempts have been made to prescribe a diet consisting of natural plant products to support the therapy of pregnant women with various infections. Urinary tract infections constitute a large fraction of these infections. In order to avoid the use of antibiotics, cranberries and their extracts, which exhibit anti-bacterial properties, are now often recommended as an alternative therapy. Dietary supplements containing cranberries are also used in veterinary medicine in urinary tract infections in dogs and cats (Guay 2009). It was reported that the A-type procyanidin isolated from cranberry juice exhibited an anti-adhesive effect against E. coli binding to urinary tract epithelial cells. However, there is no sufficient clinical evidence that cranberry type-A proanthocyanidins are effective at lowering the risk of urinary tract infection (Guay 2009, Jepson et al. 2012, Vasileiou et al. 2013). Some authors did not show the effectiveness of cranberry used versus placebo (McMurdo et al. 2005).

Dugoua et al. (2008) suggest that consumption of cranberry in pregnancy is safe but they also indicated that there is no direct evidence of safety or harm to the mother or fetus as a result of consuming cranberry during pregnancy. Moreover, late effects of such a therapy in newborns during their adult life have never been explored, and conviction of its safety is not supported by any experimental evidence. Conversely, there are reasons to suspect that cranberry therapy may not be safe for the fetus. Cranberries contain many polyphenolic compounds with proven anti-angiogenic activity on tumor angiogenesis: phenolic acids and flavonoids, including catechins and catechin polymers which are strongly antiangiogenic procyanidins (Roy et al. 2002, Kiran et al. 2008, Kanjoormana and Kuttan 2010, Kim et al. 2012). Moreover, it has been shown that triterpenoid ursolic acid, which is present in cranberries, inhibits not only tumor angiogenesis, but also inhibits embryonal angiogenesis in experiments on chicken embryos (Sohn et al. 1995). Previously, we described the inhibitory effect of Żuravit, a diet supplement containing cranberry extract, on tumor angiogenesis in mice (Skopiński et al. 2013).

As demonstrated by our previous studies, chocolate and its compounds given to pregnant mice exerted an anti-angiogenic effect and generated some abnormalities in the developing fetus. In these earlier experiments we tested the effects which feeding pregnant and lactating mice with theobromine, caffeic acid or chocolate had on humoral and cellular immune response in their 6 week old progeny. We also investigated the effects of these compounds and a mixture of cocoa catechins (catechin, epicatechin, epigallocatechin) on the angiogenic activity of 19-day embryo tissues. Angiogenic activity of embryonic tissues correlated negatively with their epigallocatechin content. Feeding pregnant mice with chocolate decreased the relative length of limbs and thigh bones in the 4-week old progeny, with accompanying bone mineralization disorder. In the six week-old progeny of mice fed with chocolate, theobromine or caffeic acid we observed elevated antibody titer in response to SRBC and suppression of some cellular immunity parameters. In chocolate and caffeic acid groups elevated levels of serum creatinine and urea were observed; in the kidneys of the chocolate group morphometrical changes were observed (lower number of glomeruli and with greater diameter than in the controls). In the theobromine group no functional or morphological changes in kidneys were seen (Skopiński et al. 2003, Skopińska-Różewska et al. 2004a,b, Wasiutyński et al. 2005, Patera et al. 2006). All this data lead to a strong suspicion that increased intake of cranberries during pregnancy and lactation, especially in the form of highly concentrated extracts, might affect embryonal, fetal and postnatal angiogenesis, as well as later in the postnatal period, the maturation and functional activity of the offspring's organs. Lack of empirical studies aiming to clarify this problem could result in increased incidence of immune system deregulation, renal failure and other possible disturbances in adult children whose mothers took such supplements during pregnancy. Thus, the aim of this preliminary research was to signal the problem and to evaluate some effects of feeding mice during pregnancy and lactation one of the dietary supplements present in the market, containing concentrated 
extract of cranberry fruit, on the selected morphometric parameters of adult offspring spleen and kidney. Previously, we confirmed the in vivo antiangiogenic effect of this supplement on tumor-induced angiogenesis in mice (Skopiński et al. 2013).

\section{Materials and Methods}

Mice. Experiments were conducted on the 6-week old progeny of 18 adult inbred females of Balb/c strain (Mossakowski Medical Research Centre, Polish Academy of Sciences), 8-9 week old, 19-21 g of body mass, mated with adult males from the same strain.

Treatment of mice. 8 females, since copulatory plug was noted, up to the 28-th day after delivery were fed with cranberry supplement dissolved in distilled water at a $44 \mathrm{mg} / \mathrm{kg}$ b.m. daily dose (Żuravit, Herbapol Lublin, Poland; one capsule contains $220 \mathrm{mg}$ of cranberry extract from $5500 \mathrm{mg}$ of fruit). This dose is equivalent to one capsule (human dose) according to the calculation based on body surface area (Shin et al 2010). Previous studies have shown that this dose inhibited angiogenesis induced in mice by tumor cells (Skopiński et al. 2013). Ten mothers served as a control group. Females were housed separately and to avoid stress connected with handling and gavage, the cranberry supplement was applied on a corn crisp, and served to the mice in a Petri dish. Control mice received distilled water applied on a corn crisp. For all experiments animals were handled according to the Polish regulation concerning the wellbeing of laboratory animals (Polish National Institute of Health) standards. All experiments were accepted and conducted according to the ethical guidance of the Local Bioethical Committee (permission 20/2012). The mice were maintained under conventional conditions (room temperature $22.5-23.0^{\circ} \mathrm{C}$, relative humidity $50-70 \%, 12 \mathrm{~h}$ day/night cycle) with free access to breeding rodent feed (Labofeed H, Factory of Fodder Morawski, Kcynia, Poland) and water. 24 days after delivery the pups were withdraws from the mothers and female and male progeny were housed separately.

Preparation of organs for cytological and histological analysis. Experiments were performed on six-week old progeny mice of both sexes. The mice were weighted, retro-orbitally bled under anesthesia [intraperitoneal injection of ketamine $(120 \mathrm{mg} / \mathrm{kg})$ and xylazine $(12 \mathrm{mg} / \mathrm{kg})$; Polypharm S.A., Warsaw, Poland] and sacrificed (pentobarbital, $400 \mathrm{mg} / \mathrm{kg}$ b.m. Polypharm S.A.). Sera were separated by $1 \mathrm{~h}$ clotting (room temperature), centrifuged at $2000 \mathrm{x}$ g for 20 min, $4^{\circ} \mathrm{C}$ and stored at $-70^{\circ} \mathrm{C}$ until required. The spleen, kidneys, thymus and liver were isolated, and weighed. Fifteen spleens from the control group and seven spleens from the descendants of the cranberry-fed group were kept for cytological study. The rest of the organs were fixed in $4 \%$ buffered formalin and processed for light microscopy. The relative weight of each organ was calculated as a ratio: the weight of organ $(\mathrm{mg})$ divided by body mass $(\mathrm{g})$. Histological evaluation (spleen, kidney, thymus, liver) and quantitative analyses (spleen and kidney) were performed on hematoxylin-eosin - stained paraffin cross-sections of the organs obtained from the progeny (10 mice from the control group and 10 mice from the experimental group). Histo-technical criteria used for quantitative analysis of spleen sections were as follows: a) thickness 3-5 $\mu \mathrm{m}, \mathrm{b}$ ) no evidence of traumatic artefacts within the sample (e.g.: fragmentation, hemorrhages), c) the complete cross-section of the spleen including white and red pulp structures and, d) the complete frontal section of the kidney including cortex, medulla and renal pelvis structures. The light microscopic examination was based on the standard morphological criteria. The examination was made using a Delta Optical Evolution 100 TRINO optical microscope (Delta Optical; Mińsk Mazowiecki, Poland) connected to a photometric color CCD camera (UCMOS05100KPA; Hangzhou ToupTek Photonics Co., Ltd., Hangzhou, China). All acquired pictures were processed using ToupView software (version 3.7; ToupTek Photonics Co., Ltd.).

Morphometric evaluation of spleen. Spleen preparations were examined using a panchromatic lens, numerical aperture: 0.25 , using 10 times zoom (total magnification $100 \mathrm{x}$ ). The whole cut surface of the cross-section of the spleen was analyzed with respect to: a) the total area and total number of white pulp lymphatic nodules with the results expressed as the number per microscopic field $\left(5.5 \mathrm{~mm}^{2}\right)$ and $\mathrm{b}$ ) lymphatic nodule diameters measured in consecutive nodules of each sample.

Morphometric evaluation of kidney. Kidney preparations were examined using a panchromatic lens, numerical aperture: 0.65 , using 40 times zoom (total magnification $400 \mathrm{x}$ ). The whole cut surface of the frontal section of the kidney was analyzed in respect to: a) the total cortical area and total number of glomeruli with the results expressed as the number $/ 1$ $\mathrm{mm}^{2}$ and b) glomeruli diameters measured in consecutive glomeruli of each sample.

Preparation of splenocyte suspension. Spleens collected from 15 descendants of control mice, and from seven descendants of mice fed cranberry extract, were gently pressed through a sterile nylon strainer $(40 \mu \mathrm{m})$ to a $50 \mathrm{ml}$ tube (Falcon) with $20 \mathrm{ml}$ of medium (RPMI 1640 with $10 \%$ FBS). The strainers were rinsed twice with medium to remove all remaining cells. The cells were the centrifuged $(500 \mathrm{x} \mathrm{g}, 5 \mathrm{~min}$.), 
the pellet was re-suspended in medium and cells counted in the hematological analyzer (Exigo, Boule Medical AB). Splenocyte viability was determined using the trypan blue method and amounted to over $95 \%$ of living cells.

Phenotypic determination of splenocytes was performed according to Lewicki et al (2015). Briefly, a spleen cell suspension $\left(100 \mu \mathrm{l}, 1 \times 10^{6} \mathrm{cell} / \mathrm{ml}\right)$ was washed twice with PBS and centrifuged $(500 \mathrm{x} \mathrm{g}$, $5 \mathrm{~min}$, room temperature). The pellet was resuspended in $100 \mu \mathrm{l}$ of PBS and labeled by surface staining with the following fluorochrome-conjugated anti-mouse antibodies against a number of cell surface markers: Mouse T lymphocyte Subset Antibody Cocktail with Isotype Control [monoclonal: hamster anti-mouse phycoerythrin (PE)-Cyanine 7 cluster of differentiation (CD) rat anti-mouse 3e, PE CD4 and rat anti-mouse allophycocyanin (APC) CD8a; cat. no 558431], Mouse B Lymphocyte Activation Antibody Cocktail with Isotype Control (monoclonal: rat anti-mouse PE-Cy7 CD25, and rat anti-mouse APC CD19; BD Bioscences, Warsaw, Poland; cat. no. 558063), according to the manufacturer's instructions (20 min. of incubation, room temperature). Red blood cells from spleens were lysed (10 min, Lysing Solution cat. no. 349202; BD Biosciences, Warsaw, Poland). Phenotypic analysis was then performed using flow cytometry (FACSCalibur; BD, San Diego, CA, USA). Results of this analysis are presented as the mean $\%$ of splenic leukocytes \pm standard error of the mean.

Anti-sheep red blood cell (SRBC) CD2 antibody production. Sixteen 6 -week old progeny mice (7 from the experimental and 9 from the control group) were immunized with $5 \%$ SRBC $(0.2 \mathrm{ml}$ intraperitoneal injection, GrasoBiotech, Starogard Gdański, Poland) 7 days prior to being bled under anesthesia from the retro-orbital plexus. Anti-SRBC antibody levels were evaluated by performing hemagglutination assay on a series of dilutions of sera, as previously described (Skopińska-Różewska et al 2009). Briefly, after inactivation $\left(56^{\circ} \mathrm{C}, 30 \mathrm{~min}\right), 1 \%$ SRBC was added to the sera and the mixture was incubated for $60 \mathrm{~min}$ at $37^{\circ} \mathrm{C}$, followed by a further $18 \mathrm{~h}$ at $4^{\circ} \mathrm{C}$, then centrifuged $\left(10 \mathrm{~min}, 150 \mathrm{x} \mathrm{g}, 4^{\circ} \mathrm{C}\right)$ and shaken. The hemagglutination titer was evaluated using light microscopy as the highest dilution in which $\geq 3$ cell conglomerates were present in $\geq 3$ consecutive fields at an objective magnification of $\times 20$. For the purposes of statistical analysis, the results were transformed into logarithm inversions of the titers.

Biochemical analysis of progeny sera. Creatinine (Jaffe method compensated) and urea concentrations were evaluated from serum using the enzymatic colorimetric method, according to the manufac- turer's protocol (BioSystems, Barcelona, Spain). Results are presented as mean $\mathrm{mg} \% \pm \mathrm{SEM}$. The concentration of VEGF and bFGF in sera were determined by ELISA tests ( $\mathrm{R}$ D Systems, Minneapolis, USA) according to the producer's protocols. All analyses were performed in duplicate.

Statistical analysis. Shapiro-Wilk normality test, Mann-Whitney test and unpaired t test were used (GraphPadPrism, Saint Diego, USA). The results are presented as mean \pm SEM, or median with range.

\section{Results}

All animals survived, during the whole experiment they were in a satisfactory condition. No unusual special features in the animal behavior were observed. The state of fur, mucosas, and quantity and consistency of feces did not show a toxic effect of the preparation. Body mass of 6- week old offspring amounted to $18.22 \pm 0.24 \mathrm{~g}$ (progeny of control mothers $\mathrm{n}=34$ ) and $18.19 \pm 0.52 \mathrm{~g}$ (progeny of cranberry extract fed mothers, $n=24)$.

Spleen. No macroscopic abnormalities are noticed in the anatomy of spleens in either the experimental or the control group. Similarly, no difference in spleen relative weight is observed between the groups $(5.6 \pm 0.1$ in the control $n=25,5.3 \pm 0.2$ in experimental group $n=17)$. Splenic lymphatic nodules are large, with well-developed germinal centers. The red pulp of the spleen is moderately plethoric. In the progeny of experimental $\mathrm{E}$ group the lymphatic nodules are less frequent and larger in comparison with the control animals (Fig. 1A and 1B). Morphometric analysis did confirm differences between experimental and control group in the number of lymphatic nodules per microscopic field and their diameter. 298 lymphatic nodules were present in 32 microscopic fields of preparations derived from the 10 spleens of the control group and 218 in 38 fields of preparations from 10 experimental group spleens. The difference between the means is highly statistically significant $(\mathrm{p}<0.0001$, Fig. 2A). On the other hand, nodules in the spleens of the experimental group were highly significantly higher than in the control spleens $(p<0.0001$, Fig. 2B). Spleens of experimental (E) group contained significantly more lymphocytes with CD8 marker (cytotoxic/suppressor T cells) and significantly more lymphocytes with CD19 marker (B lymphocytes) than spleens of the control group (Fig. 3). The CD4/CD8 ratio was $2.28 \pm 0.08$ for the controls and $1.82 \pm 0.07$ for the cranberry group, the difference is statistically significant, $\mathrm{p}<0.05$. The $\mathrm{CD} 3 / \mathrm{CD} 19$ ratio was $1.62 \pm 0.07$ in the $C$ group and $1.28 \pm 0.06$ in the E group, $\mathrm{p}<0.05$. 
A)

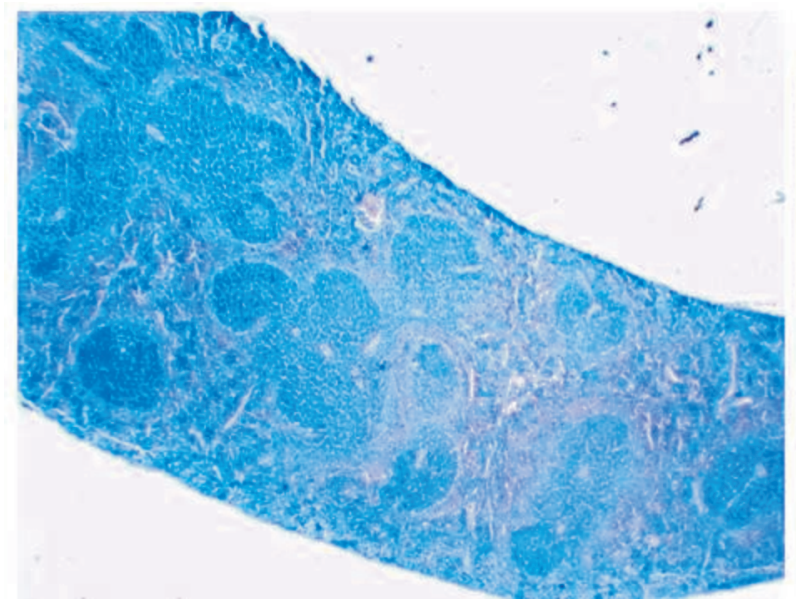

B)

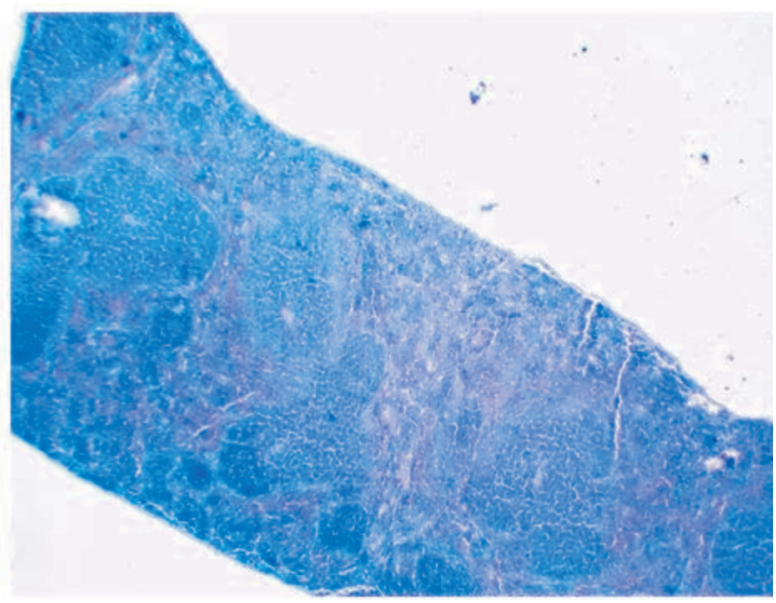

Fig. 1. A: Normal spleen (progeny of control C group). B: Spleen of progeny from cranberry E group. Note enlarged white pulp that containing central germinal centers with surrounding mantle zone and pale staining marginal zone. HE stain. $\mathrm{x} 100$.

A)

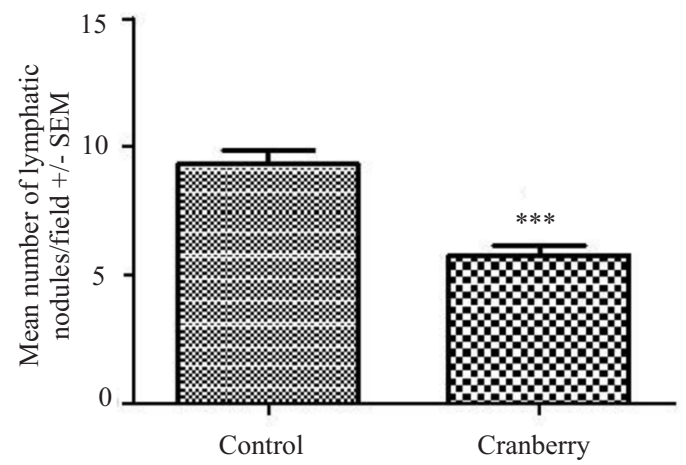

B)

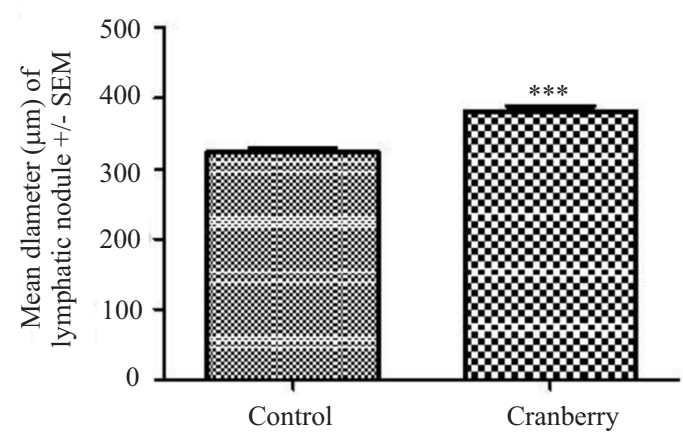

Fig. 2. Results of morphometric analysis of the spleens: mean number of lymphatic nodules (A, left) and mean diameter of nodule (B, right). Spleens were obtained from the 10 offspring of mice fed the extract of cranberries and from the 10 offspring of control mothers. ${ }^{* * *} \mathrm{p}<0.0001$

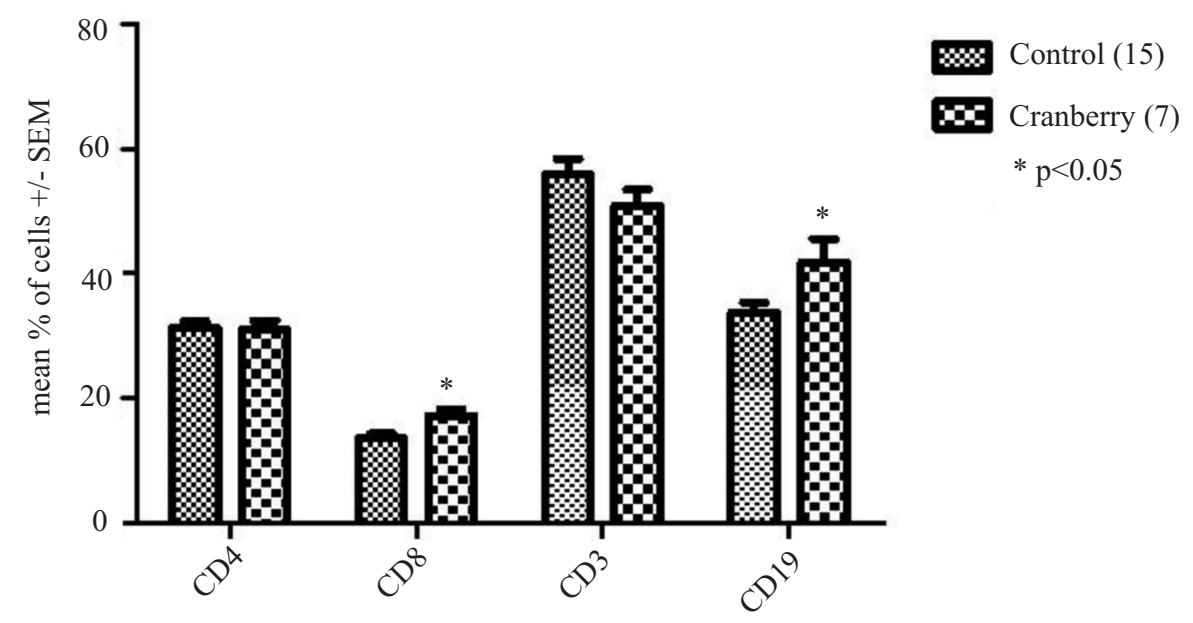

Fig. 3. Splenic lymphocyte CD markers. Spleens were obtained from the 7 offspring of mothers fed the extract of cranberries and from the 15 offspring of control mothers. * $\mathrm{p}<0.05$ 
Table 1. Morphometric analysis of renal glomeruli in control (10) and experimental (10) progeny mice.

\begin{tabular}{lcccc}
\hline Groups & $\begin{array}{c}\text { Number of analysed } \\
\text { images }\end{array}$ & $\begin{array}{c}\text { Number of analysed } \\
\text { glomeruli }\end{array}$ & $\begin{array}{c}\text { Mean diameter } \\
\text { of glomerulus }(\mu \mathrm{m}) \pm \text { SEM }\end{array}$ & $\begin{array}{c}\text { Statistical significance } \\
\text { of differences from } \\
\text { the control }\end{array}$ \\
\hline Control & 32 & 355 & $50.0 \pm 0.5$ & - \\
\hline Cranberry & 58 & 692 & $51.5 \pm 0.4$ & $\mathrm{p}<0.05$ \\
\hline
\end{tabular}

Kidney. No macroscopic abnormalities were found in the anatomy of kidneys and no differences were found between the control and experimental group in kidney relative weight $(7.1 \pm 0.1, \mathrm{n}=25$ in the control and $7.2 \pm 0.2, \mathrm{n}=17$ in the experimental group). Histologically normal glomeruli and nephron structures were observed in both groups. Degenerative changes were not been detected. Morphometric analysis did not reveal differences between the number of glomeruli per microscopic field (Fig. 4.). However, slight yet statistically significant glomerular hypertrophy was found, manifested as larger diameter of glomeruli in the experimental than in the control group (Table 1).

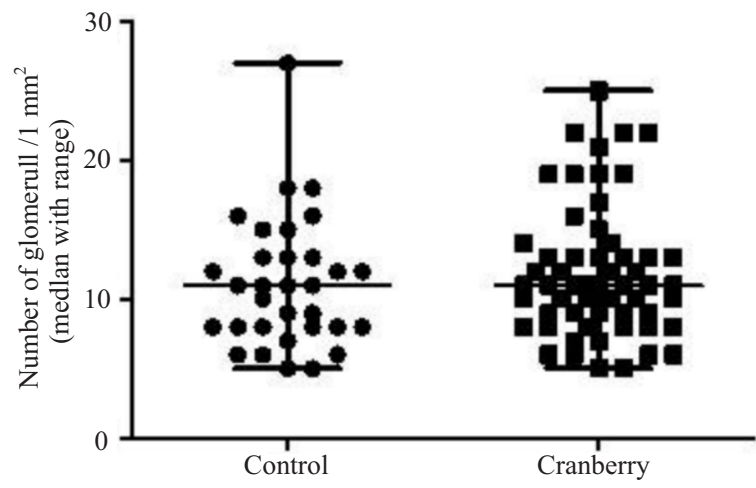

Fig. 4. Results of morphometric analysis of the renal glomeruli number per $1 \mathrm{~mm}^{2}$ microscopic field. There are no differences between the kidneys obtained from the 10 offspring of mice fed an extract of cranberries and kidneys obtained from the 10 progeny of control mothers.

No differences between both groups were seen in respect to the sera creatinine and urea levels. Creatinine concentration was $0.51 \pm 0.05$ and $0.41 \pm 0.05$ $\mathrm{mg} / \%$ in the control $(\mathrm{n}=17)$ and experimental $(\mathrm{n}=13)$ group, respectively. Urea concentration was $50.1 \pm 1.5$ in the control and $49.9 \pm 1.3 \mathrm{mg} \%$ in the experimental group. VEGF and bFGF concentrations were higher $(p<0.05)$ in the sera of E-group progeny than in the controls (VEGF $85.4 \pm 2.9 \mathrm{pg} / \mathrm{ml}$ in the controls $(n=8)$ versus $110.9 \pm 8.9(n=5)$ in the $E$ sera; bFGF $11.6 \pm 1.9 \mathrm{pg} / \mathrm{ml}$ in the controls versus $30.8 \pm 5.3$ in the progeny of cranberry-fed mothers.

Thymus. No macroscopic irregularities were observed. No difference in the thymus relative weight was observed between the groups $(3.8 \pm 0.1, n=25$ in the control, and $3.6 \pm 0.2, \mathrm{n}=17$ in the experimental group). Microscopically, in the control group the thymus structure has specific features, common in mice. Numerous lobules are separated with connective tissue. In the cortex lymphocytes and lymphoblasts are predominant. Large clear epithelial cells are present in the medulla. The vessels of the medulla are plethoric. In the experimental group no changes as compared to the control were observed. No hyperplasia or atrophy of the thymus was detected.

Liver. No macroscopic irregularities are seen. No difference in the liver relative weight is observed between the groups $(53.7 \pm 1.5, \mathrm{n}=25$ in the control, and $53.1 \pm 2.5 \mathrm{I}, \mathrm{n}=17$ in experimental group). Microscopically, both in the control and experimental group the hepatic tissue has ordinary lobular and trabecular structure. The hepatocytes have distinct borders, well stained nuclei and slightly granular cytoplasm. The Disse spaces are not expanded. The content of the Kuppfer cells, and lympho-histiocytic infiltration of the stroma do not differ from the norm.

Anti-SRBC antibodies. No difference was found between log titers of anti- SRBC antibodies in sera of control mice progeny $(3.66 \pm 0.23, \mathrm{n}=9)$ and progeny of mice fed cranberry extract $(3.41 \pm 0.42, n=7)$.

\section{Discussion}

The present study showed morphological and morphometric changes in the spleens of mice born to mothers fed extract of cranberries during gestation. It was manifested as a reduced number of white pulp follicles with accompanying hypertrophy and large germinal centers. Cytometry revealed an increased number of $\mathrm{CD}^{+}$( $\mathrm{T}$ suppressor/cytotoxic) and CD19 ${ }^{+}$ (B) lymphocytes. The question arises - what is the function of these "extra" CD8 and CD19 cells present in the spleens of mice from experimental (American cranberry) group. Jiang et al (2007) described a model of immunological tolerance, in which $\mathrm{CD}^{+}$Foxp $^{+}$ splenocytes seemed to play an important role. We intend, in the near future, to carry out a more detailed study of splenocytes, among others, to investigate the presence of markers characteristic for regulatory 
T and B cells (Saze et al. 2013, Schuler et al. 2014, Figueiro et al. 2016).

Hypertrophic changes in renal glomeruli might be connected with increased concentration of bFGF and VEGF in the sera of $E$ group progeny. It was reported that VEGF is an important regulator of glomerular endothelial cell functionality and both its overproduction and deficiency may lead to glomerulopathies (Kumar and Molitoris 2015). It was demonstrated that polyphenols (catechins, phenolic acids) may inhibit the activation of tyrosine kinase VEGF receptors and VEGF and bFGF production (Bałan et al. 1999, Shimizu et al. 2010). The increased serum concentration of these growth factors in the present study may then be connected with rebound phenomenon. Similar results are reported for progeny of mice fed epigallocatechin during pregnancy and lactation (Lewicki et al. 2017).

In recent research on the influence of Rhodiola kirilowii extracts on the splenocytes of pregnant mice, a negative correlation between spleen cellularity and catechin content and a positive correlation between spleen cellularity and quercetin content were observed (Lewicki et al. 2015). Quercetin is a major flavonoid in cranberry fruit (Choi et al. 2001, Ferguson et al. 2006). Characterization of an active subfraction of proanthocyanidins revealed the presence of dimers and oligomers of catechin-epicatechin, monomeric catechins, and quercetin glycosides (Neto 2007). Flavonoids are a large group of polyphenolic compounds with multidirectional and often contradictory actions. They regulate key targets related to oxidative stress and inflammation. It has been reported that polyphenol-rich foods, when ingested during the third trimester of pregnancy, may influence the dynamics of fetal ductus arteriosus flow through inhibition of prostaglandin synthesis (Zielinsky and Busato 2013, Ly et al. 2014). There are also reports of embryotoxicity of catechins in vitro against murine embryos at the blastocyst stage (Tu et al. 2010, Fan and Chan 2014). Yoshida et al. (2013) presented inhibitory effects of catechin derivatives on mammalian DNA polymerase and topoisomerase activities and mouse one-cell zygote development. However, in the present study we noticed no significant difference between the percentage of mothers in the control and the experimental group of females mated with males, which argues against an early toxic effect of cranberry extract. There are also papers which describe the beneficial effects of a diet rich in flavonoids in pregnancies at risk of premature birth, caused by infection and accompanying inflammation. (Lim et al. 2014, Morwood and Lappas 2014).

Compounds found in cranberries showed a high anticancer activity with different mechanisms of ac- tion. The large group of anticancer properties of cranberries is connected with antiangiogenic activity. Research has repeatedly proven that anthocyanins, proanthocyanidins, ursolic acid, quercetin and triterpene acids have antiangiogenic activity, and inhibit tumor progression and metastasis (Bagchi et al. 2004, Cardenas et al. 2004, Donnini et al. 2006). Cranberries may be expected to inhibit carcinogenesis and tumor angiogenesis in part by influencing the expression of matrix metalloproteinases (MMPs). MMPs are involved in proteolysis of the extracellular matrix, which can lead to the progression of tumors (Pupa et al. 2002). Proanthocyanidins, quercetin and ursolic acid, reduced both the expression and activity of MMPs. Cranberries and their extracts, owing to their anti-microbial, anti-inflammatory and anti-angiogenic activities can be a valuable addition, or an alternative natural remedy, in various pathological states (Blumberg et al. 2013). However, their impact on angiogenesis, which is beneficial in the case of tumors or inflammatory diseases, may be harmful in the case of the developing embryo and fetus. The morphological disorder of the spleen that we observed during the present study, in conjunction with a slight, but statistically significant hypertrophy of renal glomeruli, add to the extensive evidence we have gathered so far but constitute merely a stepping stone on the long way ahead of us. We intend to further examine the effects in older progeny through the use of our experimental model.

\section{Conclusion}

Although the observed differences between the control and experimental group were not large, caution is recommended in using cranberries and their extracts during pregnancy until more research is done on this topic.

\section{References}

Bagchi D, Sen CK, Bagchi M, Atalay M (2004) Anti-angiogenic, antioxidant and anti-carcinogenic properties of novel anthocyanin-rich berry extract formula. Biochemistry (Mosc) 69: 75- 80.

Bałan BJ, Skopińska-Różewska E, Sokolnicka I, Gawrychowski K, Strzelecka H (1999) The effect of selected phenolic acids on angiogenic activity of ovarian cancer cells - preliminary report. Onkol Pol 2: 203-208.

Blumberg JB, Camesano TA, Cassidy A, Kris-Etherton P, Howell A, Manach C, Ostertag LM, Sies H, Skulas-Ray A, Vita JA (2013) Cranberries and their bioactive constituents in human health. Adv Nutr 4: 618-632.

Cardenas C, Quesada AR, Medina MA (2004) Effects of ursolic acid on different steps of the angiogenic process. Biochem Biophys Res Commun 320: 402-408. 
Choi JA, Kim JY, Lee JY, Kang CM, Kwon HJ, Yoo YD, Kim TW, Lee YS, Lee SJ (2001) Induction of cell cycle arrest and apoptosis in human breast cancer cells by quercetin. Int J Oncol 19: 837-844.

Donnini S, Finetti F, Lusini L, Morbidelli L, Cheynier V, Barron D, Williamson G, Waltenberger J, Ziche M (2006) Divergent effects of quercetin conjugates on angiogenesis. Br J Nutr 95: 1016-1023.

Dugoua JJ, Seely D, Perri D, Mills E, Koren G (2008) Safety and efficacy of cranberry (Vaccinium macrocarpon) during pregnancy and lactation. Can J Clin Pharmacol 15: e80-e86.

Fan YC, Chan WH (2014) Epigallocatechin gallate induces embryonic toxicity in mouse blastocysts through apoptosis. Drug Chem Toxicol 37: 247-254.

Ferguson PJ, Kurowska EM, Freeman DJ, Chambers AF, Koropatnick J (2006) In vivo inhibition of growth of human tumor lines by flavonoid fractions from cranberry extract. Nutr Cancer 56: 86-94.

Figueiro F, Muller L, Funk S, Jackson EK, Battastini AM, Whiteside TL (2016) Phenotypic and functional characteristics of CD39high human regulatory B cells (Breg). Oncoimmunology 5: e1082703.

Fuleki T, Francis FJ (1968) Quantitative methods for anthocyanins. Purification of cranberry anthocyanins. J Food Sci 33: 266-274.

Guay DR (2009) Cranberry and urinary tract infections. Drugs 69: 775-807.

Hecht A (1979) Drug safety labeling for doctors. FDA Consum 13: 12-13.

Jepson RG, Williams G, Craig JC (2012) Cranberries for preventing urinary tract infections. Cochrane Database Syst Rev 10: CD001321.

Jiang L, Yang P, He H, Li B, Lin X, Hou S, Zhou H, Huang $X$, Kijlstra A (2007) Increased expression of Foxp3 in splenic CD8+T cells from mice with anterior-chamber - associated immune deviation. Mol Vis 13: 968-974.

Kanjoormana M, Kuttan G (2010) Anti-angiogenic activity of ursolic acid. Integr Cancer Ther 9: 224-235.

Kim KK, Singh AP, Singh RK, Demartino A, Brard L, Vorsa N, Lange TS, Moore RG (2012) Anti-angiogenic activity of cranberry proanthocyanidins and cytotoxic properties in ovarian cancer cells. Int J Oncol 40: 227-235.

Kiran MS, Viji RI, Sameer Kumar VB, Sudhakaran PR (2008) Modulation of angiogenic factors by ursolic acid. Biochem Biophys Res Commun 371: 556-560.

Lewicki S, Skopińska-Różewska E, Bałan BJ, Kalicki B, Patera J, Wilczak J, Wasiutyński A, Zdanowski R (2017) Morpho-functional renal alterations in progeny of mice fed Rhodiola kirilowii extracts or epigallocatechin during pregnancy and lactation. J Med Food 20: 86-92.

Lewicki S, Stankiewicz W, Skopińska-Różewska E, Wilczak J, Leśniak M, Suska M, Siwicki AK, Skopiński P, Zdanowski R (2015) Spleen content of selected polyphenols, splenocytes morphology and function in mice fed Rhodiola kirilowii extracts during pregnancy and lactation. Pol J Vet Sci 18: 847-855.

Lim R, Morwood CJ, Barker G, Lappas M (2014) Effect of silibinin in reducing inflammatory pathways in in vitro and in vivo models of infection-induced preterm birth. PLoS One 9: e92505.

Ly C, Yockell-Lelievre J, Ferraro ZM, Arnason JT, Ferrier J, Gruslin A (2015) The effects of dietary polyphenols on reproductive health and early development. Hum Reprod Update 21: 228-248.
McMurdo ME, Bissett LY, Price RJ, Phillips G, Crombie IK (2005) Does ingestion of cranberry juice reduce symptomatic urinary tract infections in older people in hospital? A double blind, placebo-controlled trial. Age Ageing 34: 256-261.

Morwood CJ, Lappas M (2014) The citrus flavone nobiletin reduces pro-inflammatory and pro-labour mediators in fetal membranes and myometrium: implications for preterm birth. PLoS One 9: e108390.

Neto CC (2007) Cranberry and its phytochemicals: a review of in vitro anticancer studies. J Nutr 137(Suppl 1): 186S-193S.

Patera J, Chorostowska-Wynimko J, Słodkowska J, Borowska A, Skopiński P, Sommer E, Wasiutyński A, Skopińska-Rózewska E (2006) Morphometric and functional abnormalities of kidneys in the progeny of mice fed chocolate during pregnancy and lactation. Folia Histochem Cytobiol 44: 207-211.

Pupa SM, Menard S, Forti S,Tagliabue E (2002) New insights into the role of extracellular matrix during tumor onset and progression. J Cell Physiol 192: 259-267.

Roy S, Khanna S, Alessio HM, Vider J, Bagchi D, Bagchi M, Sen CK (2002) Anti-angiogenic property of edible berries. Free Radic Res 36: 1023-1031.

Saze Z, Schuler PJ, Hong CS, Cheng D, Jackson EK, Whiteside TL (2013) Adenosine production by human B cells and $\mathrm{B}$ cell-mediated suppression of activated $\mathrm{T}$ cells. Blood 122: 9-18.

Schuler PJ, Saze Z, Hong CS, Muller L, Gillespie DG, Cheng D, Harasymczuk M, Mandapathil M, Lang S, Jackson EK, Whiteside TL (2014) Human CD4 ${ }^{+}$CD39 ${ }^{+}$ regulatory $\mathrm{T}$ cells produce adenosine upon co-expression of surface CD73 or contact with $\mathrm{CD}^{2} 3^{+}$exosomes or $\mathrm{CD}^{+} 3^{+}$cells. Clin Exp Immunol 177: 531-543.

Shimizu M, Shirakami Y, Sakai H, Yasuda Y, Kubota M, Adachi S, Tsurumi H, Hara Y, Moriwaki H(2010) (-)-Epigallocatechin gallate inhibits growth and activation of the VEGF/VEGFR axis in human colorectal cancer cells. Chem Biol Interact 185: 247-252.

Shin JW, Seol IC, Son CG (2010) Interpretation of animal dose and human equivalent dose for drug development. J Korean Orient Med 31: 1-7.

Skopińska-Różewska E, Bałan BJ, Sommer E, Chorostowska-Wynimko J, Bany J, Wasiutyński A, Siwicki AK (2004a) The influence of chocolate feeding of pregnant mice on the immunological response of their progeny. Pol J Food Nutr Sci 13: 67-70.

Skopińska-Różewska E, Chorostowska-Wynimko J, Rogala E, Radomska-Leśniewska D, Skopiński P, Sommer E, Siwicki AK (2004b) Caffeic acid feeding of pregnant and lactating mice influences the immune response of their progeny. Pol J Food Nutr Sci 13: 63-66.

Skopińska-Różewska E, Mościcka-Wesołowska M, Wasiutyński A, Małdyk J, Malejczyk M, Pazdur J (1985) Lymphatic system of mice born from mothers treated with ampicillin or cloxacillin during gestation. Arch Immunol Ther Exp (Warszawa) 34: 203-208.

Skopińska-Różewska E, Siwicki AK, Sommer E (2009) Stimulation of humoral immunity in mice by some commercial fragrances. Centr Eur J Immunol 34: 232-234.

Skopiński P, Skopińska-Różewska E, Sommer E, Chorostowska-Wynimko J, Rogala E, Cendrowska I, Chrystowska D, Filewska M, Bialas-Chromiec B, Bany J (2003) Chocolate feeding of pregnant mice influences length of limbs of their progeny. Pol J Vet Sci 6 (Suppl 3): 57-59. 
Skopiński P, Zdanowski R, Bałan BJ, Siwicki AK, Kocik J, Lewicki S, Suska M, Pastewka K, Skopińska-Różewska E, Demkow U (2013) Aloe arborescens and American cranberry (Vaccinium macrocarpon) extracts inhibit tumor-induced cutaneous angiogenesis in mice. Cent Eur J Immunol 38: 480-485.

Sohn KH, Lee HY, Chung HY, Young HS, Yi SY, Kim KW (1995) Anti-angiogenic activity of triterpene acids. Cancer Lett 94: 213-218.

Tu HC, Chen CP, Chan WH (2010) Epicatechin gallate decreases the viability and subsequent embryonic development of mouse blastocysts. Taiwan J Obstet Gynecol 49: $174-180$

Vasileiou I, Katsargyris A, Theocharis S, Giaginis C (2013) Current clinical status on the preventive effects of cranberry consumption against urinary tract infections. Nutr Res 33: 595-607.

Verma SK, Molitoris BA (2015) Renal endothelial injury and microvascular dysfunction in acute kidney injury. Semin Nephrol 35: 96-107.
Wasiutyński A, Siwicki AK, Bałan BJ, Sommer E, Bany J, Wąsik M, Prątnicki A, Skurzak H, Skopińska-Różewska E (2005) Inhibitory effect of cocoa catechins on embryonic and tumor angiogenesis in mice. Pol $\mathrm{J}$ Environm Studies 14: 800-805.

Włodarska B, Bany J, Marczak M, Korczak-Komorowski A, Polakowski IJ, Pazdur J, Skopińska-Rózewska E (1987) Altered immune reactivity of mice born from mothers treated with ampicillin during gestation. Folia Biol (Praha) 33: 210-215.

Yoshida N, Kuriyama I, Yoshida H, Mizushina Y (2013) Inhibitory effects of catechin derivatives on mammalian DNA polymerase and topoisomerase activities and mouse one-cell zygote development. J Biosci Bioeng 115: 303-309.

Zielinsky P, Busato S (2013) Prenatal effects of maternal consumption of polyphenol-rich foods in late pregnancy upon fetal ductus arteriosus. Birth Defects Res C Embryo Today 99: 256-274. 